\title{
Intrabases divergences in the mHealth era: a drug interaction investigation in an infectious-diseases hospital setting
}

Divergências intrabases na era mHealth: investigação de interações medicamentosas em um hospital de doenças infecciosas

Divergencias entre las bases en la era de la mHealth: investigación de las interacciones farmacológicas en un hospital de enfermedades infecciosas

\begin{abstract}
Introduction: Information on potential drug interactions (PDI) are obtained from databases available on the web or through mobile healthcare applications (mHealth), and can prevent unfavorable clinical outcomes for patients. This study compared PDI information available in Micromedex ${ }^{\circledR}$ drug interaction checker, its web version and its $m$ Health app. Method: A cross-sectional study realized based on a retrospective review of drug prescriptions in a reference hospital in infectology in the Midwest Region of Brazil, 2018. We selected all prescriptions containing two or more drugs. Drugs were classified according to the first level of the Anatomical Therapeutic Chemical (ATC) classification, according to the route of administration and the number of drugs prescribed. PDIs were classified according to the severity system and four-level evidence classification system. Results: This study selected 72 patients, predominantly male, median age of 38 years, average length of stay of 15.8 days, and most diagnosed with HIV/AIDS. The most frequently prescribed anatomical groups according to ATC were digestive system and metabolism (22.1\%) and general anti-infectives for systemic use (21.6\%). The average number of drugs per prescription was 10.8 (SD \pm 6.7$)$. The Micromedex ${ }^{\circledR}$ mHealth app found 381 PDIs while its web version detected 502 PDIs, with an average of 5.3 and 7.0 and frequency of $61.1 \%$ and $72.2 \%$, respectively. According to the severity classification in $m$ Health and web versions, the following stood out, respectively: 221 and 321 severe; 139 and 149 moderate. The majority (>65\%) of identified PDIs had their documentation classified as reasonable. Conclusion: Digital tools although they aid decisionmaking, are not unanimous and consistent in detecting such interactions.
\end{abstract}

Keywords: Drug prescriptions; Infectology; Mobile device; Drug interaction; Mobile health; Smartphone.

\section{Resumo}

Introdução: Informações sobre interações medicamentosas potenciais (IMP) podem ser obtidas em bases de dados disponíveis na web ou por meio de aplicativos móveis em saúde (mHealth), e podem evitar desfechos clínicos desfavoráveis aos pacientes. Este estudo comparou as informações de IMP disponíveis no verificador de interações medicamentosas Micromedex®, em sua versão disponível na web e seu aplicativo mHealth. Métodos: Realizou-se estudo transversal com base em revisão retrospectiva de prescrições de medicamentos em hospital de referência em infectologia da Região Centro-Oeste do Brasil, 2018. Selecionamos todas as prescrições contendo dois ou mais 
medicamentos. Os medicamentos foram classificados de acordo com o primeiro nível da classificação Anatomical Therapeutic Chemical (ATC), de acordo com a via de administração e o número de medicamentos prescritos. As IMP foram classificados de acordo com o sistema de gravidade e sistema de classificação de evidências em quatro níveis. Resultados: Foram selecionados 72 pacientes, com predomínio do sexo masculino, mediana de idade de 38 anos, tempo médio de internação de 15,8 dias, e maioria com diagnóstico de HIV/Aids. Os grupos anatômicos mais frequentemente prescritos segundo ATC foram aparelho digestivo e metabolismo $(22,1 \%)$ e anti-infecciosos gerais para uso sistémico $(21,6 \%)$. O número médio de fármacos por prescrição foi de 10,8 (DP $\pm 6,7)$. Encontrou-se 381 IMP em Micromedex® mHealth enquanto sua versão web detectou 502 IMP, com média de 5,3 e 7,0 e frequência de $61,1 \%$ e $72,2 \%$, respectivamente. Segundo a classificação de gravidade na versão mHealth e web, destacaram-se respectivamente: 221 e 321 graves; 139 e 149 moderadas. A maioria (>65\%) das IMP identificadas tiveram a sua documentação classificada como razoável. Conclusão: As ferramentas digitais, embora auxiliem na tomada de decisão, não são unânimes e concordantes na detecção de IMP.

Palavras-chave: Prescrições de medicamentos; Infectologia; Dispositivo móvel; Interação medicamentosa; Saúde móvel; Smartphone.

\begin{abstract}
Resumen
Introducción: La información sobre posibles interacciones medicamentosas (PIF) se puede obtener de las bases de datos disponibles en la web o mediante aplicaciones de atención médica móviles, y puede evitar resultados clínicos desfavorables para los pacientes. Este estudio comparó la información de IMP disponible en el verificador de interacción de medicamentos Micromedex ${ }^{\circledR}$, su versión web y su aplicación mHealth. Metodos: Se realizó un estudio transversal basado en una revisión retrospectiva de prescripciones de medicamentos en un hospital de referencia en enfermedades infecciosas en la Región Medio Oeste de Brasil, 2018. Seleccionamos todas las prescripciones que contienen dos o más medicamentos. Los fármacos se clasificaron según el primer nivel de la clasificación Anatómico Terapéutico Químico (ATC), según la vía de administración y el número de fármacos prescritos. Los PIF se clasificaron según el sistema de gravedad y el sistema de clasificación de evidencia de cuatro niveles. Resultados: Se seleccionaron 72 pacientes, predominantemente varones, mediana de edad de 38 años, estancia media de 15,8 días y la mayoría diagnosticados de VIH / SIDA. Los grupos anatómicos prescritos con mayor frecuencia según ATC fueron aparato digestivo y metabolismo $(22,1 \%)$ y antiinfecciosos generales de uso sistémico $(21,6 \%)$. El número medio de medicamentos por prescripción fue de 10,8 (DE $\pm 6,7)$. Se encontraron 381 IMP en Micromedex ${ }^{\circledR} m$ Health mientras que su versión web detectó $502 \mathrm{PIF}$, con un promedio de 5.3 y 7.0 y una frecuencia de $61.1 \%$ y $72.2 \%$, respectivamente. Según la clasificación de gravedad en las versiones $m$ Health y web, se destacaron, respectivamente: 221 y 321 graves; 139 y 149 moderado. La documentación de la mayoría (> 65\%) de los IMP identificados se clasificó como razonable. Conclusión: Las herramientas digitales, aunque ayudan en la toma de decisiones, no son unánimes y coincidentes en la detección de Según la clasificación de gravedad en las versiones mHealth y web, se destacaron, respectivamente: 221 y 321 graves; 139 y 149 moderado. La documentación de la mayoría (> 65\%) de los IMP identificados se clasificó como razonable. Conclusión: Las herramientas digitales, aunque ayudan en la toma de decisiones, no son unánimes y coincidentes en la detección de PIF.

Palabras clave: Prescripciones de medicamentos; Infectología; Dispositivo móvil; La interacción de drogas; Salud móvil; Smartphone.
\end{abstract}

\title{
1. Introduction
}

In 2018 infectious diseases were responsible for more than 700 thousand hospitalizations in Brazil (Brasil, 2019). World Health Organization (WHO) data show that hospitalized patients tend to be in polypharmacy regimens- use of five or more comedications - which is considered one of the main risk factors for drug-drug interactions (DDI) (WHO, 2017a).

In this context, the identification of potential DDI (PDDI) is essential to avoid unfavorable clinical outcomes. Currently, information about PDDI, traditionally available on websites, can be also accessed through mobile health applications (mHealth). These tools make access to drug information easier and more versatile in the dynamic setting of bedside-care.

Annually, 44,000 to 98,000 deaths in the United States occur due to medication errors (Committee on Quality of Health Care in America, 2000). In this context, the dynamism provided by mHealth apps can contribute to the safe use of medicines.

Although mHealth apps could enhance contemporary health practice, important divergences in PDDI identification, severity classification and its clinical management have been shown by comparative studies (Pauly, et al., 2014). 
In this context, we conducted a study on potential drug-drug interactions in prescriptions of hospitalized patients admitted into an infectious disease referral hospital and we compared PDDI information's available in web drug interactions checker and their related mHealth apps.

\section{Material and Methods}

We conducted cross-sectional study based on a retrospective review of drug prescriptions, available in electronic medical records, from a referral infectology hospital in Center-West Region of Brazil, 2018. This study was approved by the Research Ethics Committee of State Hospital for Tropical Diseases Dr. Anuar Auad under registration CAAE. 81074117.8.0000.0034. Center-West Region of Brazil, 2018. This study was approved by the Research Ethics Committee of State Hospital for Tropical Diseases Dr. Anuar Auad under registration CAAE. 81074117.8.0000.0034. During the study period, there were 130 active beds in the institution. All hospitalized individuals were included, except those coming from day hospital beds, due to the short length of stay ( $<12$ hours). We calculated mean, median, standard deviation for continuous variables and frequency for categorical variables.

A census was conducted on a date determined by electronic draw, data collection took place on a single day, in March 2018. We selected all prescriptions containing two or more medications. Individuals sociodemographic data and clinical characteristics were extracted from the SOUL MV Hospitalar@ software (version 2000), which is the main software system comprising all the hospital's patient data, using an own standard author form. Data were analyzed using the Epi info® platform (version 7.2.2.6 CDC, Atlanta Georgia - USA), Excel® (version 2013) and OpenEpi® (version 3.01). We calculated mean, median, standard deviation for continuous variables and frequency for categorical variables.

The drugs were classified according to the first level system (anatomical or pharmacological groups) of the World Health Organization's Anatomical Chemical Therapeutic Classification (ATC) (WHO, 2017b). Additionally, the drugs were classified according to the route of administration and the number of prescribed drugs: a) two to four medications; b) polypharmacy (5-9 comedications); c) excessive polypharmacy ( $\geq 10$ comedications). The platform IBM Micromedex ${ }^{\circledR}$ Drug Interaction Checking (IBM Micromedex ${ }^{\circledR}$ Drug Interaction Checking, 2018) platform (Micromedex ${ }^{\circledR}$ ) was elected for this study because of its widespread use in the literature and its recognized sensitivity and specificity in identifying PDDI (Jodlowski et al., 2011; Reis \& Cassiani, 2011; Cedraz \& Santos, 2014). Thus, the PDDI were classified according to the fivelevel severity system and the four-level documentation rating system, as described in Table 1. 
Table 1 - Classification of potential drug-drug interactions regarding severity and quality of documentation, Micromedex ${ }^{\circledR}$ database

\begin{tabular}{|cl|}
\hline & \multicolumn{1}{c|}{ Potential Drug Interactions } \\
\hline Classification & Documentation \\
\hline Excellent & Documentation strongly suggests interaction, but robust studies are lacking. \\
Good & Available documentation is limited, but there is pharmacological evidence. \\
Fair & Drugs are contraindicated for concomitant use. \\
\hline Classification & $\begin{array}{l}\text { Interaction may be life-threatening and may require medical intervention to reduce or prevent serious adverse } \\
\text { reactions. } \\
\text { Contraindicated }\end{array}$ \\
Major & $\begin{array}{l}\text { Interaction may result in aggravation of the health problem or require change in treatment. } \\
\text { Moderate }\end{array}$ \\
Minor & Interaction may result in limited clinical effects. There may be increased frequency of side effects. \\
\hline
\end{tabular}

Source: IBM Micromedex® Drug Interaction Checking (2018). Adapted by the authors.

\section{Results}

We selected 72 individuals and their respective drug prescriptions. Among these, $76.4 \%(n=55)$ were hospitalized in wards, $5.5 \%(n=4)$ in the emergency room and $18 \%(n=13)$ in an intensive care unit. The median age was 38 years, ranging from 1 to 82 . Most individuals were male, $80 \%$ of them lived in urban areas and the average length of stay was 15.8 days (range 1 to 200). Approximately half of the individuals were hospitalized due to AIDS (Table 2). 
Table 2 - Socio-demographic and clinical characteristics of individuals admitted to a referral infectology hospital, centralwestern Brazil, 2018.

\begin{tabular}{|c|c|c|c|}
\hline Variables & Classification & $\mathbf{N}$ & $\%$ \\
\hline \multirow[t]{2}{*}{ Sex } & Male & 47 & 65.3 \\
\hline & Female & 25 & 34.7 \\
\hline \multirow[t]{3}{*}{ Age (years) } & $\leq 14$ & 12 & 16.0 \\
\hline & $15-59$ & 51 & 70.7 \\
\hline & $\geq 60$ & 9 & 13.3 \\
\hline \multirow[t]{3}{*}{ Marital status $^{\mathrm{a}}$} & Married & 16 & 27.6 \\
\hline & Single & 38 & 65.5 \\
\hline & Others $^{\mathrm{b}}$ & 4 & 6.9 \\
\hline \multirow[t]{2}{*}{ Race $^{\mathrm{c}}$} & White & 6 & 8.5 \\
\hline & Mixed / Black & 65 & 91.5 \\
\hline \multirow[t]{4}{*}{ Scholarity (years) ${ }^{d}$} & $<3$ & 11 & 36.7 \\
\hline & $4-7$ & 6 & 20.0 \\
\hline & $8-10$ & 3 & 10.0 \\
\hline & $>10$ & 10 & 33.3 \\
\hline \multirow[t]{7}{*}{ Diagnosis $\left(\right.$ CID 10) ${ }^{\mathrm{e}}$} & AIDS & 33 & 45.8 \\
\hline & Pneumonia & 8 & 11.1 \\
\hline & Influenza & 9 & 12.5 \\
\hline & Tuberculosis & 3 & 4.2 \\
\hline & Dengue & 3 & 4.2 \\
\hline & Venomous animais & 3 & 4.2 \\
\hline & Others $^{\mathrm{f}}$ & 13 & 18.1 \\
\hline
\end{tabular}

${ }^{a}$ Missing data from 14 individuals.

${ }^{\mathrm{b}}$ Others, Divorced: 3; Widower: 1.

${ }^{\mathrm{c}}$ Missing data from 1 individual.

${ }^{\mathrm{d}}$ Missing data from 42 individuals.

'International Classification of Diseases (ICD-10), WHO 2008; B20-B24: Human Immunodeficiency Virus Disease; J12-J18: Pneumonia; J09-J11: Influenza; A15: Respiratory tuberculosis; A91: Haemorrhagic Fever Due to Dengue Virus; T63: Toxic Effect of Venomous Animal Poison.

f Others, B41: Paracoccidioidomycosis; B55: Leishmaniasis; A30: Leprosy; A41: Other septicemia; A86: Viral Encephalitis; J43: Emphysema; J96: Respiratory failure; K70: Alcoholic hepatitis; L03: Cellulitis; L10: Pemphigus Vulgaris; R59: Localized swelling of lymph nodes.

Source: Authors.

An overall of 779 medications were prescribed, with an average of 10.8 (SD \pm 6.7 ) drugs per prescription (range 2 to 30). Most of them were administered intravenously ( 60\%). Among the prescribed drugs, there were 126 distinct active substance that were classified into 11 ATC groups, of which $86 \%(n=669 / 779)$ were classified in four groups (A, B, J and N) (Table 3).

Polypharmacy was identified in more than $80 \%$ of prescriptions $(\mathrm{p}<0.000002)$, with a higher frequency among young / adults people aged 15 to 59 years with a frequency of $84.3 \%$ (95\% CI 72.0-91.8\%), followed by $83.3 \%$ (95\% CI 55.295.3\%) among children and in 77.8\% (95\% CI 45.3-93.7\%) among elderly individuals ( $p=0.98)$. The prevalence of excessive polypharmacy ( $\geq 10$ comedication) was $45.8 \%$ (95\% CI 34.8-57.3\%) and its occurrence was also observed in all age groups, affecting $25 \%$ of children, $49 \%$ of young/adults people and $55.5 \%$ of the elderly; $(p=0.57$ ) (Table 3 ). 
Table 3 - Characteristics of drug prescriptions from patients admitted to a referral hospital in infectology, central-western Brazil, 2018.

\begin{tabular}{lcc}
\hline Variable & N & \% \\
Prescribed drugs & & \\
$2-4$ & 12 & 16.7 \\
$5-9$ & 27 & 37.5 \\
$\geq 10$ & 33 & 45.8 \\
\hline Polypharmacy, $\geq \mathbf{5}$ medicines & \\
Child & 10 & 16.7 \\
Youth / Adult & 43 & 71.6 \\
Elderly & 7 & 11.7 \\
\hline Administration Routes ${ }^{\text {a }}$ & & \\
IV & 464 & 59.6 \\
VO & 173 & 22.2 \\
Others* & 138 & 18.2 \\
\hline Classification ATC ${ }^{\text {b }}$ & & \\
A (Digestive system and Metabolism) & 172 & 22.1 \\
B (Blood and Hematopoietic organs) & 167 & 21.4 \\
J (Anti-infective agents for systemic use) & 168 & 21.6 \\
N (Nervous system) & 162 & 20.8 \\
Others** & 110 & 14.1 \\
\hline
\end{tabular}

${ }^{\text {a }}$ IV: intravenous; VO: oral;

*Others, VE: enteral; IN: inalatória; SC: subcutaneous ; IM: intramuscular.

${ }^{\mathrm{b}}$ Classificacion Anatomical Therapeutic Chemical (ATC), WHO 2017.

**Others, C: Cardiovascular system; R: Respiratory system; H: Hormones for systemic use; M: Musculoskeletal system; D: Dermatological; G: Genitourinary system and sex hormones; P: Antiparasitic Products; V: Several.

Source: Authors.

Among 779 most commonly prescribed drugs from 126 active substances, sodium chloride and dipyrone were used by more than $80 \%$ of study participants (Table 4). We could not find any information about dipyrone and bromopride, the second and fourth most commonly medication prescribed, in the mHealth version of Micromedex®. Dipyrone and Bromopride are widely prescribed in Brazil, unlike most foreign countries, including the United States.

Table 4 - Most prescribed active substance among patients admitted to a referral infectology hospital, central-west Brazil, 2018.

\begin{tabular}{|c|c|c|c|}
\hline \multirow[b]{2}{*}{ Active substance a } & \multirow[b]{2}{*}{ ATC Classification } & \multicolumn{2}{|c|}{ Individuals } \\
\hline & & $\mathbf{N}$ & $\%$ b \\
\hline Sodium Chloride & B05 - Blood substitutes and infusion solutions. & 63 & 87.5 \\
\hline Dipyrone & N02 - Analgesics. & 58 & 80.5 \\
\hline Dextrose & B05 - Blood substitutes and infusion solutions. & 44 & 61.1 \\
\hline Bromopride & A03 - Antispasmodic, anticholinergic and propulsive agents. & 37 & 51.4 \\
\hline Ondansetron & A04 - Antiemetics and antinauseants. & 33 & 45.8 \\
\hline Sulfamethoxazole/Trimethoprim ${ }^{c}$ & J01 - Antimicrobials for systemic use. & 28 & 38.8 \\
\hline Omeprazole & A02 - Antacids and drugs for the treatment of peptic ulcer. & 28 & 38.8 \\
\hline
\end{tabular}

\footnotetext{
a Active ingredients with a prescription frequency greater than $30 \%$ were selected.

${ }^{\mathrm{b}}$ Data presented in decreasing form, the frequency of individuals who were prescribed the presented active substance.

${ }^{\mathrm{c}}$ Sulfamethoxazole/Trimethoprim.

Source: Authors.
} 


\section{Analysis of Potential Drug-Drug Interactions}

In this study analyzed prescriptions, at least one PDDI was found in $73.6 \%(\mathrm{n}=53)$ of its total. From a total of 505 PDDIs, 75\% ( $\mathrm{n}=378)$ represents the intersection of identified ones in both Micromedex ${ }^{\circledR}$ versions. The web and mHealth version individually identified 502 and 381 PDDI, respectively. The PDDI average per prescription varied according to database version, being $7(\mathrm{Dp} \pm 8.3)$ in web version and $5.3(\mathrm{Dp} \pm 6.8)$ in mHealth version $(\mathrm{p}=0.52)$.

Among the 126 distinct active substance identified in this study, five of them (tenoxicam, ringer lactate, dipyrone, nitrazepam and bromopride) were not available in the mHealth database, resulting in 124 PDDI, classified as contraindicated $(\mathrm{n}=11)$, major $(\mathrm{n}=103)$, moderate $(\mathrm{n}=10)$ that could not be detected by this version. In contrast, three severe PDDI, related to the combination of codeine-acetaminophen with comedications, were uniquely identified by mHealth app.

The severity rating showed that more than $60 \%$ of PDDI were contraindicated or severe and most of them (> 65\%) were classified with documentation rated as reasonable (Figure 1). Figure 1 illustrates PPIs classified as severe, with frequency $\geq 0.6 \%$, represented by constantly prescribed drugs. The arrows indicate IMP between the communicating parts. Bold are drugs with high frequency of IMP, which are only in the web version database., are they: Trimethoprim+Sulfamethoxazole : SXT; Rifampicin, Isoniazid and Pyrazinamide: RHZ. 
Figure 1 - Severe PDDI identified in prescriptions of individuals admitted to a referral hospital in Infectious Diseases, Central West, 2018.

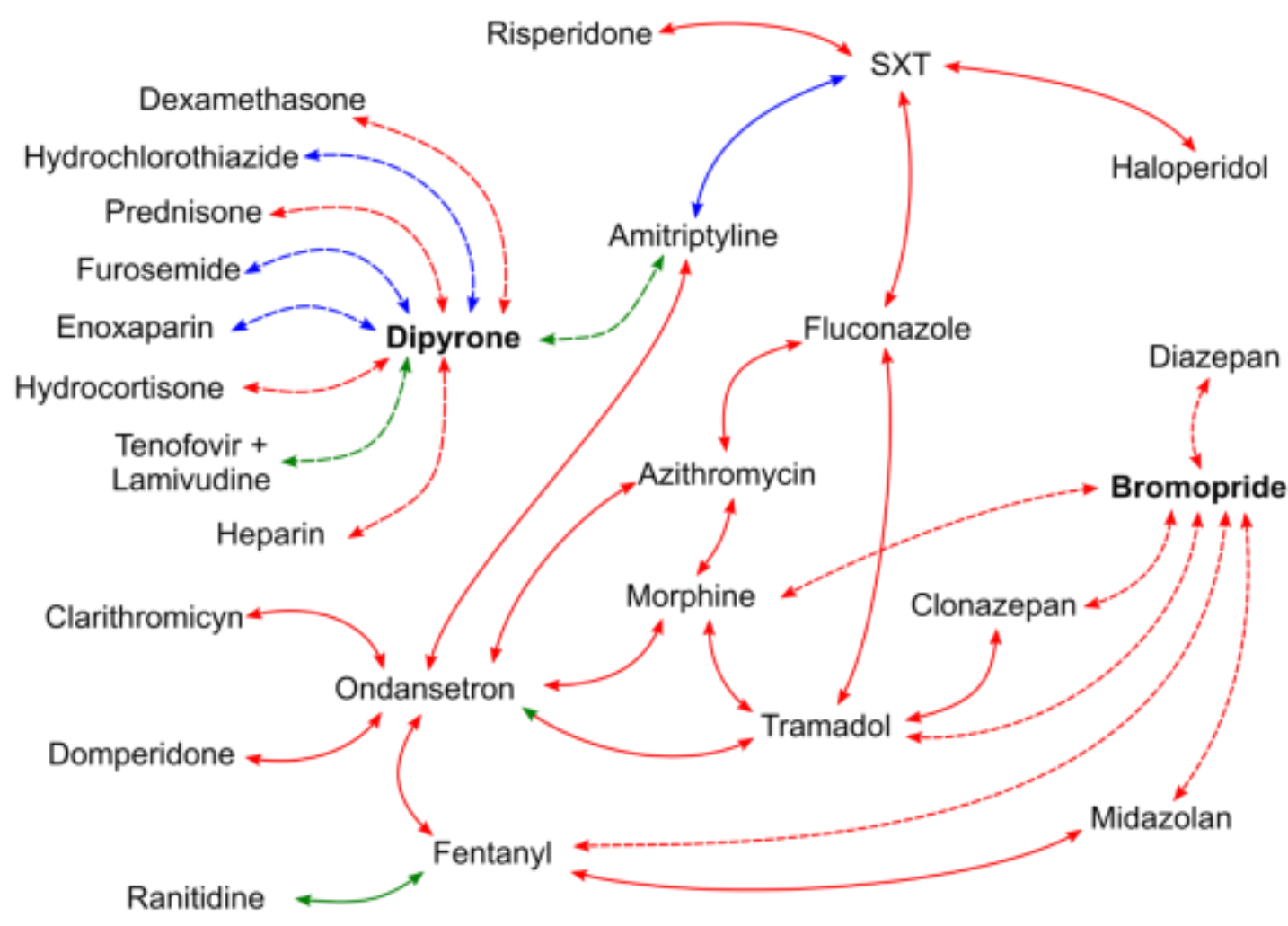

$\mathrm{RHZ}$

Acetominophen

\section{Documentation}

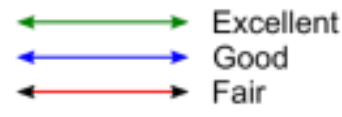

PDDI found on web e mHealth versions.

PDDI found only on web version.

Source: Authors.

There were 31 types of ART-related-PDDIs, the most common of them were found between dipyrone and the combination of tenofovir + lamivudine $1.4 \%(n=7 / 502)$.

\section{Discussion}

Our study analyzed drugs prescribed to individuals admitted to a reference hospital in infectology in the central-west of Brazil in order to investigate the occurrence of PDDI but also their information provided by two different versions (web and mHealth app) of the same database. Most of the participants in this study were young people or adults, who were in use of analgesics and antimicrobials, and half of the overall investigated population were individuals living with HIV/AIDS. More than $80 \%$ of individuals were under polypharmacy $(\mathrm{p}<0.01)$ and a prevalence of $73.6 \%$ of PDDI was identified. 
Two versions of the Micromedex ${ }^{\circledR}$ database were used in order to identify and classify PDDI and important differences among those data were detected. These differences are mainly explained by the lack of information in the mHealth version on interactions involving the drugs dipyrone, bromopride, tenoxicam, nitrazepam and ringer lactate solution. In this setting, the mHealth version of Micromedex ${ }^{\circledR}$ was in disadvantage, since it did not got updates that contemplated information related to drugs commonly used in Brazil.

Dipyrone, the second most prescribed drug in our study, was identified in 76 PDDIs comedications pairs, about $87 \%$ of which were classified as severe. Dipyrone relevant clinical data could not be evaluated in the mHealth version scenario since this application not presented this drug in the available list.

Dipyrone is classified as a non-steroidal analgesic and anti-inflammatory drug (NSAID) and its effects as analgesic and antipyretic are unquestionable (Rang, et al., 2007). In Brazil dipyrone is included in the list of over-the-counter drugs (OTC) (ANVISA, 2020). However, safety information about the use of this medicine diverges, mainly because of the rare but serious adverse reactions such as aplastic anemia, Stevens-Johnson syndrome, toxic epidermal necrosis and agranulocytosis (Magni, et. al., 2010).

Drug interactions related to bromopride, which could not be identified in the mHealth version, accounted for $9 \%$ $(n=44)$ of total PDDI identified, 10 of them were considered contraindicated and 34, severe; both due to the risk of extrapyramidal reactions. The incidence of these reactions may be even higher when intravenous doses of bromopride are required, a warning alert, since more than a half of the drugs analyzed in this study were administered by this route (Tonini, et. al., 2004).

We highlighted that 116 antimicrobial-related-PDDI were identified in both versions of Micromedex® database which is a relevant event since the study setting was a referral infectology hospital. The most common antimicrobial-relatedPDDIs were: sulfamethoxazole + trimethoprim $(6.8 \%)$, azithromycin $(4.8 \%)$ and rifampicin + isoniazid + pyrazinamide (4.6\%). Yet, among those, severe PDDI identified were: azithromycin and fluconazole, azithromycin and ondansetron as well as sulfamethoxazole + trimethoprim and fluconazole, which were related to the risk of ventricular arrhythmias (QT interval prolongation) and ventricular fibrillation (Roden, et al., 2016).

It is worth highlight that azithromycin, among others antimicrobials, show electrophysiological effects similar to class III antiarrhythmic drugs (MARTINS et al., 2015) and fluconazole may prolong the QT interval, either directly or by inhibiting the hepatic metabolism of other agents that have direct action under this signal, such as atazanavir an antiretroviral drug involved in treatment of HIV infections (Molloy, et al., 2018).

About a half of the analyzed population was living with HIV/AIDS and almost $20 \%$ of individuals were on antiretroviral therapy (ART). In these setting, DDI may be an adjuvant factor in ART failure and an important cause of prejudice in treatment adherence (Molas, et al., 2018). The most frequent ART-related interaction of dipyrone and the combination of tenofovir + lamivudine $1.4 \%(\mathrm{n}=7 / 502)$ is related to the risk of renal failure, so patients should be adequately monitored for glomerular filtration rate (GFR), especially patients with GFR> $60 \mathrm{~mL} / \mathrm{min}$. Additionally, it is noteworthy that this PDDI could not be detected in the mHealth version (Machado, et. al., 2014).

Monitoring ART-related-PDDIs is essential to improve the treatment of people living with HIV (PLHIV) (BRASIL, 2013). In this study, information provided by The Micromedex ${ }^{\circledR}$ web version indicated that all patients on ART had at least one interaction associated with antiretroviral drugs, while the mHealth version showed at least one ART-related-PDDI in 70\% of prescriptions. Although the present study was conducted with prescriptions of hospitalized patients, where the chances of self-medication are minimized, it was found that the scenario regarding the occurrence of PDDIs is not more optimistic than that in an outpatient treatment setting, whose PDDIs prevalence varied from $23.6 \%$ to $52.2 \%$ according studies conducted in different regions of Brazil (Cascao, et al., 2017; Santos, et al., 2016). 
The majority of participants underwent to the main risk factor for PDDIs since according to the literature, polypharmacy is the main risk factor for drug interactions (Monegat et al., 2014). Approximately $80 \%$ of the individuals in our study received prescriptions with 5 or more medications, and a half of the young and adults individuals received prescriptions containing 10 or more comedications (excessive polypharmacy).

This study innovates since it brings highlights to intrabases divergences in the mHealth era trough comparative information about PDDIs in different versions (mHealth and web) of a largely database (Micromedex®) applied in the literature. In addition, the present study also contributes in a better comprehension of the occurrence of PDDIs in hospitalized patients in a infectious diseases scenario, an unusual theme in the PDDIs investigation setting. Our study presents as its main limitation the impossibility of verifying if, in fact, such identified PDDIs occurred in clinical practice, though we did not have the propose to investigate it, since patient follow-up was not within the scope of this study.

Access to computerized databases, electronic prescriptions and alert programs are mechanisms of remarkable importance for the prevention and management of drug interactions (Correr \& Otuki, 2013). However, it is necessary to standardize the contents of these databases and their different versions, so that any doubts on the appropriate clinical management are properly addressed.

\section{Conclusion}

This study demonstrated a high frequency of polypharmacy and a high frequency of contraindicated and severe pDDIs in prescriptions of hospitalized patients at a referral hospital in infectious diseases, Center-West Region of Brazil. Despite the clear advantages related to the versatility, mobility and optimization in the use of Micromedex ${ }^{\circledR}$ mHealth version in clinical practice, we have identified that pDDIs information related to frequently prescribed drugs in Brazil, such as dipyrone and bromopride, was only available in the web version of the database.

\section{References}

Cascao, P. C. (2017). Interações medicamentosas potenciais associadas à Terapia Antirretroviral. Dissertação. Dissertação de Mestrado, Faculdade de Medicina UFG, Goiânia, Brasil.

Cedraz, K. N. \& Santos, M. C. J. (2014) Identificação e caracterização de interações medicamentosas em prescrições médicas da unidade de terapia intensiva de um hospital público da cidade de Feira de Santana, BA. Sociedade Brasileira de Clínica Médica, 2 (1), 12. http://files.bvs.br/upload/S/1679. 1010/2014/v12n2/a4178.pdf

Correr, J. \& Otuki, M. A. (2013). Prática Farmacêutica na Farmácia Comunitária (1a ed.). Porto Alegre: Artmed.

Prereira, A. S., Shitsuka, D. M., Parreira, F. J., Shitsuka, R. (2018). Metodologia da Pesquisa Científica. Núcleo de Tecnologia Educacional, Universidade Federal de Santa Maria, Santa Maria, RS. https://repositorio.ufsm.br/bitstream/handle/1/15824/Lic_Computacao_Metodologia-PesquisaCientifica.pdf?sequence $=1$

IBM. (2019). Micromedex® Drug Interaction Checking (electronic version). IBM Wastson Health, Greenwood Village, Colorado, USA. http://www.micromedexsolutions.com

Institute of Medicine (US) Committee on Quality of Health Care in America, Kohn, L. T., Corrigan, J. M., \& Donaldson, M. S. (Eds.). (2000). To Err is Human: Building a Safer Health System. National Academies Press (US).

Jodlowski, T. Z., Patel, P. N., Maische, N. M., Mildvan, D. (2011) Comparison of online drug interaction databases to evaluate antiretroviral medication interactions. Pharmacotherapy Journal, 31 (10), 312. Retrieved from: http://e-lactancia.org/media/papers/Metoprolol-BuprenorfinaBF-Pharmacother2011.pdf

Magni, A. M., Scheffer, D. K., Bruniera, P. (2011) Comportamento dos antitérmicos ibuprofeno e dipirona em crianças febris. Jornal de Pediatria, 87( 1 ), 3642 .

Machado, J. A. E., Morales, C. D. P., Hoyos, V. S. (2014). Frecuencia de potenciales interacciones medicamentosas entre antirretrovirales y otros grupos farmacológicos en pacientes colombianos. Investigaciones Andina, 16(28), 910-920. http://www.scielo.org.co/scielo.php?script=sci_arttext\&pid=S0124$81462014000100005 \& \operatorname{lng}=$ en $\&$ tlng=.

Martins, J. M., Figueirêdo, T. P., Costa, S. C., Reis, A. M. M. Medicamentos que podem induzir prolongamento do intervalo QT utilizados por idosos em domicílio. Ciência Farmacêutica Básica Aplicada. 2015; 32 (2): 297-305. 
Research, Society and Development, v. 10, n. 14, e559101417156, 2021

(CC BY 4.0) | ISSN 2525-3409 | DOI: http://dx.doi.org/10.33448/rsd-v10i14.17156

Molas, E., Luque, S., Retamero, A., Echeverría-Esnal, D., Guelar, A., Montero, M., Guerri, R., Sorli, L., Lerma, E., Villar, J., \& Knobel, H. (2018). Frequency and severity of potential drug interactions in a cohort of HIV-infected patients Identified through a Multidisciplinary team. HIV clinical trials, 19(1), 1-7. https://doi.org/10.1080/15284336.2017.1404690

Molloy, S. F., Bradley, J., Karunaharan, N., Mputu, M., Stone, N., Phulusa, J., Chawinga, C., Gaskell, K., Segula, D., Ming, D., Peirse, M., Chanda, D., Lakhi, S., Loyse, A., Kanyama, C., Heyderman, R. S., \& Harrison, T. S. (2018). Effect of oral fluconazole $1200 \mathrm{mg} /$ day on QT interval in African adults with HIVassociated cryptococcal meningitis. AIDS (London, England), 32(15), 2259-2261. https://doi.org/10.1097/QAD.0000000000001961

Monegat, M., Sermet, C., \& Rococo, E. (2014). Polypharmacy: Definitions, Measurements and stakes involved in review of literature and measurement test. Questions d'économie de la santé 204 (20), 1-8.

National Health Surveillance Agency [Agência Nacional de Vigilância Sanitária - ANVISA]. (2020). Pharmacovigilance Bulletin No. 9 [Boletim de Farmacovigilância ${ }^{\circ}$ 9]. Brasília. Retrieved from: https://www.gov.br/anvisa/pt-br/arquivos-noticias-anvisa/917json-file-1

Pauly, A., Wolf, C., Busse, M., Strauß, A. C, Krebs, S., Dorje, F., \& Friedland, K. (2015). Evaluation of eight drug interaction databases commonly used in the German healthcare system. European Journal of Hospital Pharmacy , 22(3), 165-70. doi:10.1136/ejhpharm-2014-000561

Pereira, A. S., Shitsuka, D. M., Parreira, F. J., \& Shitsuka, R. (2018). Metodologia da Pesquisa Científica. Núcleo de Tecnologia Educacional, Universidade Federal De Santa Maria, Santa Maria, RS. https://repositorio.ufsm.br/bitstream/handle/1/15824/Lic_Computacao_Metodologia-Pesquisa-Cientifica.pdf?sequence=1

Rang, H. P., Dale, M.M, Ritter, J. M., Flower, R. J. (2007). Farmacos antiinflamatórios e immunossupressores. Elselvier.

Reis, A. M. M. \& Cassiani, S. H. B. (2011) .Prevalence of potential drug interactions in patients in an intensive care unit of a university hospital in Brazil. Clinics, 66(1), 9-15. Retrieved from: https://doi.org/10.1590/S1807-59322011000100003.

Roden, D. M. (2016). Predicting drug-induced QT prolongation and torsades de pointes. The Journal of physiology, 594(9), $2459-2468$. https://doi.org/10.1113/JP270526

Santos, W. M., Secoli, S., \& Padoin, S. Potenciais interações de drogas em pacientes de terapia antirretroviral. Rev. Latino-Am. Enfermagem. 2016;24:2832.

Tonini, M., Cipollina, L., Poluzzi, E., Crema, F., Corazza, G. R., \& De Ponti, F. (2004). Review article: clinical implications of enteric and central D2 receptor blockade by antidopaminergic gastrointestinal prokinetics. Alimentary pharmacology \& therapeutics, 19(4), 379-390. https://doi.org/10.1111/j.13652036.2004.01867.x

World Health Organization [WHO]. (2017a). Anatomic Therapeutic and Chemical Classification of Drugs. http://www.whocc.no/atcdd.

World Health Organization [WHO]. (2017a). Medication Without Harm. Who Global Patient Safety Challenge. file:///C:/Users/Rober/AppData/Local/Temp/WHO-HIS-SDS-2017.6-eng.pdf 